\title{
A World of Lies in Heart of Darkness
}

\author{
Deyan Guo \\ College of Foreign Languages, Nankai University, China; \\ School of English Studies, Tianjin Foreign Studies University, China \\ Email: guodeyan@tjfsu.edu.cn
}

\begin{abstract}
In Heart of Darkness, Joseph Conrad depicts a horrible picture of western colonization in Africa. Through Charlie Marlow, the young protagonist's journey into the depth of the primeval land and his confrontation with Kurtz, the most capable ivory collector in the Congo, Conrad exposes the cruelty and avarice of western civilization and its destructive power on both Europeans and Africans. In the meantime, Conrad brings both Marlow and the readers to discover another more agonizing truth that everyone lives in the illusions and deceptions on different levels.
\end{abstract}

Index Terms - Heart of Darkness, colonization, lies, self-deception

\section{INTRODUCTION}

Impelled by a desire for adventures, Charlie Marlow, the young British sailor, manages to obtain a contract with a Belgian company which has business in Africa. He boards a French steamer and starts a journey into the centre of the dark continent, the Congo. After a short stay at the Outer Station, he leaves with a caravan for the Central Station where he is expected to repair a wrecked steamer, by which the manager would go to rescue a man named Kurtz at the Inner Station. With the physical shift from the Outer Station to the Central Station and then to the Inner Station, Marlow penetrates step by step into the hinterland of the dark continent and metaphorically into the mysterious world of ideas embodied in Kurtz. Through his exploration into Kurtz's experience and the company's ivory trade, Marlow lifts piece by piece the beautiful veil of western civilization and brings the readers to see the truth that man is living in a world of lies and deceptions.

\section{LIES OF WESTERN CIVILIZATION}

Before 1885 the Congo had been visited and explored by Portuguese, Dutch, French and American pioneers. In 1884, Otto von Bismarck, the first chancellor of the newly formed German Empire, came to realize that a territorial, theological or trade war over the Congo would benefit no nation and called a conference in Berlin, at which he made a decision to give the Congo to King Leopold II of Belgium on the condition that King Leopold should guarantee that "all nations would be permitted to trade freely there, that taxes and tariffs would not be collected, and that nations would not be granted monopolies on particular items of trade" (Murfin, 1996, p. 6). Earlier in 1876, Leopold II had expressed his interest and ambition in the Congo that he designed to "open to civilization the only part of our globe where Christianity has not yet penetrated and to pierce the darkness which envelops the entire population" (qtd in Murfin, 1996, p.5). But his promise turned out to be a lie when he took over this land. He broke most of his commitments to Bismarck's 1884 convention by sending his agents to monopolize the ivory trade and rule the natives in the way slaveholders did to the slaves. Instead of bringing civilization to the Congo, King Leopold simply made it the mine of profit for himself and his agents.

In Heart of Darkness, Marlow is greatly appalled by the ferocity and hypocrisy of imperialism and colonialism. Under the pretext of civilizing the primitive continent of darkness, Belgian companies send their agents to trade with innocent and credulous natives for their precious ivory. In return, they give the natives cheap European stuff as calico, cotton prints, beads and so on.

To European colonizers, their only concern is trade and their survival in tropical climate. The afflictions and destruction they bring to the natives and the land are out of their minds. The most striking scene Marlow witnesses at the Outer Station is a sharp contrast between the immaculately and elegantly dressed Chief Accountant and the ghostly contorted dying Africans in the nearby inferno-like grove. Soon after Marlow leaves the grove of death, the sight of a white man with "a high starched collar, white cuffs, a light alpaca jacket, snowy trousers, a clear necktie, and varnished boots" (Conrad, 1981, p.28) impresses Marlow as meeting a "miracle," "a sort of vision." Then Marlow learns that the Chief Accountant could keep up his appearance in the unpleasant surroundings haunted by death because he has been training a native woman to do his sewing though she hates the work. A further acquaintanceship brings Marlow to question the humanity in the Chief Accountant. Marlow marvels at the accuracy and devotion of the Accountant to his work, but is shocked at his indifference to the groans of the sick agent in his office.

At the Central Station, Marlow encounters a larger group of cold and greedy whites. The manager and the pilgrims suffer the hostile environment only for the sake of ivory and hence the possible promotion at the company. Ironically 
what these pilgrims do at the station does not go parallel with the name they bear. They do nothing philanthropic. God and faith are far away from them and the only real and dear thing is ivory. Marlow feels that in their talk "the word 'ivory' rang in the air, was whispered, was sighed. You would think they were praying to it" (p. 37). As to the manager, besides praying to collect more ivory, he prays that no disturbance will occur so that he can get promoted at the company. None of them show any mercy to the natives who work for them. Even when the storage shed is on fire, they almost beat a young African to death for they believe that he has caused the fire.

In contrast to this ivory-obsessed group of whites, Kurtz at the Inner Station who proves to be the most capable ivory collector is all the time inspired by a faith to civilize the primordial land as King Leopold II claimed in his ambitious design of the Congo. Another point to differ Kurtz from this group is that he finally comes to the realization of the lie of the so-called noble cause and of the cruelty of colonialism. In this sense, Kurtz is a real man with a thinking mind and a repenting heart. While, the people like the manager and the pilgrims make themselves animals, whose only concern is to satisfy their physical need for money and success.

Of all the whites at the station, Marlow and the Russian Harlequin alone are called there by the mystery, the charm and the vastness of African land. So they have neither profit to make nor a noble cause to devote to, which gives them an advantage to keep their eyes open to what is happening to the land and its people, thus rendering an almost objective judgment on imperialism and Kurtz though their minds have been more or less shaped by western ideology.

While the Russian confirms to Marlow that the natives are simple people who mean no harm to the whites, Marlow's judgment on them undergoes a change. When he feels a touch of insanity in the firing of the French man-of-war into the empty land, someone on board assures him that there is "a camp of natives--he called them enemies!--hidden out of sight somewhere" (p. 21). Even if Marlow does not see any point in his naming the natives enemies, he does not question it for in his mind he still maintains the European bias toward Africans who are generally seen as savages or cannibals. After he sets his feet on the land, Marlow hears more pops of firing and sees the black people run in fear. When his attention is riveted on a gloomy sight of six black men chained in the neck, he can in no way associate them with enemies. They are "criminals, and the outraged law, like the bursting shells, had come to them, an insoluble mystery from the sea" (p. 24). This change from enemies to criminals marks Marlow's doubt of western racial conception. And the doubt develops into a challenge when he begins to appreciate some quality in the natives.

During their rescue journey up to the Inner Station, the starved Africans exhibit great power of restraint. For nearly one month, they have only a few lumps of some stuff like half-cooked dough to eat, "now and then swallowed a piece of, but so small that it seemed done more for the looks of the thing than for any serious purpose of sustenance" (p. 69). If they deserve their name of being cannibals, they have enough courage, strength and motive to eat up the Europeans on board. However, they do not go for them even if they outnumber the whites. Marlow finds that the only reason to refrain them from doing so is their restraint, "one of those human secrets that baffle probability, had come into play there" (p. 69). Because of their restraint, Marlow looks at them as real human beings "with a curiosity of their impulses, motives, capacities, weaknesses, when brought to the test of an inexorable physical necessity. Restraint!" (p. 69) This discovery disturbs Marlow to no small extent when he contrasts the self-restrained Africans with the Europeans who have lost their restraint in plundering the treasures out of African land and even Kurtz too has gone too far away from his restraint in brutalizing the natives for ivory and obedience. Marlow who grows up with European sense of racial superiority cannot so readily accept this new judgment and acknowledge the virtue in Africans, but at least he has taken the first step to negate European value system and reveal the true nature of western civilization.

\section{MAN'S WORLD OF LIES}

In the early 1600s, European colonizers came to America with a design to turn the virgin land into a new Garden of Eden and make it a permanent home. Therefore they explored and developed the land without doing much damage to it. In contrast, the colonizers in the late $19^{\text {th }}$ century invaded Africa with only the aim to "tear treasure out of the bowels of the land... with no more moral purpose at the back of it than there is in burglars breaking into a safe" (Conrad, 1981, p. 50). Under these circumstances, the mission to civilize the land becomes an absurd lie. But the lie is not simply confined to the abstraction of western civilization, but also extended to the people living by those abstractions.

\section{A. Men's Deceptions}

At the call of colonialism and the so-called drive of civilization, many Europeans came to Africa with a hope to try their fortune or to light up the land of darkness. They were unaware of what was awaiting them on this mysterious primitive land. Many of them had died of tropical diseases before they could lay a hand on the ivory. For those who survived, they were unfortunately trapped in the struggle for ivory and power. Such is the case with the manager, the brickmaker and the pilgrims at the Central Station.

The manager strikes Marlow as a very mediocre man with "no genius for organizing, for initiation, or for order even" (p. 34). As Marlow speculates, he could secure his position there mainly because he is never taken ill when "triumphant health in the general rout of constitutions is a kind of power in itself" (p. 35). Without giving Marlow any time for rest from the long tiring trek, the manager entrusts him to finish the repair work on the wrecked steamer within 3 months, for they have to go up to the Inner Station to rescue Mr. Kurtz who was seriously ill. The manager's compliments on Kurtz as the best agent and an exceptional man and his uneasiness about what is occurring at the Inner Station seem to 
tell Marlow that he is very concerned about Kurtz's health. While the unreasonable delay of sending for the rivets without which Marlow could not stop the hole in the steamer and the manager's startlingly accurate estimation of the time required of the repair lead Marlow to suspect of the manager's motive. One unexpected overhearing of the talk between the manager and his uncle confirms his suspicion that the manager is conspiring against Kurtz.

In the view of Cedric Watts (1977), Heart of Darkness is a murder story if a murder plot can be defined as "a scheme to delay a man's relief in conditions which virtually ensure that without prompt relief the man will succumb to disease and death" (p. 83). According to Watts, the manager has made a deliberate but seemingly guileless plot to postpone the rescue work. First he gets the steamer wrecked just 2 days before Marlow's coming, "They had started 2 days before in a sudden hurry up the river with the manager on board, in charge of some volunteer skipper, and before they had been out three hours they tore the bottom out of her on stones, and she sank near the south bank" (Conrad, 1981, p. 33-4). Secondly, he intentionally does not give the dictation to the brickmaker who writes the letter for the supplies so that Marlow cannot go on with his repair. "There were cases of them down at the coast---cases---piled up---burst---split! You kicked a loose rivet at every second step in that station-yard on the hillside... and there wasn't one rivet to be found where it was wanted (p. 45-6). Later the confidential conversation between the manager and his uncle makes it clear that the manager has no real concern about Kurtz. He hates Kurtz and would rather see him die because Kurtz's influential background at the company and his amazing capacity make himself a great obstacle in the manager's way of success. "He bothered me enough when he was here... conceive you---that ass! And he wants to be manager!" (p. 54) So when the manager defends his work, "the extraordinary series of delays is not my fault. I did my best" (p. 54), he is obviously lying. As he calculates, it takes three months for the repair and another two months for the journey up-river, then the rescue should come to Kurtz just when he is dying.

The manager depends on lies and plots to get rid of Kurtz, while at the Central Station, there is a pervading air of plotting among the pilgrims except that they have not really made it into a fact.

However, they were all waiting---all the sixteen or twenty pilgrims of them---for something; and upon my word it did not seem an uncongenial occupation, from the way they took it, though the only thing that ever came to them was disease---as far as I could see. They beguiled the time by backbiting and intriguing against each other in a foolish kind of way. There was an air of plotting about that station, but nothing came of it, of course. It was as unreal as everything else---as the philanthropic pretence of the whole concern, as their talk, as their government, as their show of work. The only real feeling was a desire to get appointed to a trading-post where ivory was to be had, so that they could earn percentages. They intrigued and slandered and hated each other only on that account — but as to effectually lifting a little finger---oh, no. (p. 39)

Though nothing comes of the "air of plotting," there is good reason to believe that these crazy pursuers of ivory will surely resort to the dirty means of lying and scheming as the manager does if someone stands in their way of success and wealth because greed for ivory and hatred to the natives have turned them into butchers.

\section{B. Women's Illusions}

While waiting for means to go to his trading post, Kurtz kills his time by painting a woman "draped and blindfolded, carrying a lighted torch. The background was somber---almost black. The movement of the woman was stately, and the effect of the torchlight on the face was sinister" (Conrad, 1981, p. 40). This painting can best describe women's circumstances. They are blindfolded and barred from the reality. Yet, different from the manager and the pilgrims who make lies and intrigues to secure their position and chances for promotion, the women characters, as Marlow believes, prefer to live in their world of illusions.

Before Marlow sets off for Africa, he pays a visit to his aunt who has helped him get that job through her relations. His self-contempt at relying on a woman evidently illustrates his patronizing view of women. "I, Charlie Marlow, set the women to work---to get a job. Heavens! Well, you see, the notion drove me" (p. 12). In any case, because of this aunt, he can gratify his fascination with that yellow region on the map, "Dead in the centre. And the river was there---fascinating---deadly---like a snake" (p. 15). As to the aunt, she is glad to be of help to Marlow partly out of her concern about Marlow's dream for that land and partly out of her noble conception that Marlow will go there as one of the Workers, "Something like an emissary of light, something like a lower sort of apostle" (p. 18). This aunt is totally inspired by the propagandizing claim of the government and keeps talking about "weaning those ignorant millions from their horrid ways" (p. 18). At this, Marlow cannot refrain his contempt toward women's ignorance. "It's queer how out of touch with truth women are. They live in a world of their own, and there has never been anything like it, and never can be. It is to beautiful altogether, and if they were to set it up it would go to pieces before the first sunset" (p. 19). From Marlow's perspective, women refuse to confront the world of facts, but would rather shut themselves in their self-created world of lies and illusions.

Another example of women confined to their own world is the two knitting women at the Company's headquarters. At the moment he enters the office, Marlow sees two women, "one fat and the other slim, sat on straw-bottomed chairs, knitting black wool" (p. 14). Their indifferent look and the older woman's "quick glance of unconcerned wisdom" (p. 16) invoke in Marlow "an eerie feeling"(p. 16) that the two women seem to be "knitting black wool as for a warm pall, one introducing, introducing continuously to the unknown, the other scrutinizing the cheery and foolish faces with unconcerned old eyes. Ave! Old knitter of black wool. Morituri te salutant”(p. 16). A metaphorical and mythical reading will associate the two knitting women with the Fates of Roman Legend: "Clotho and Lachesis, who spin the thread of 
each man's life which is to be cut by Atropos... and the fact that both women are thought of as 'guarding the door of Darkness' may evoke a fleeting memory of the Sibyl in Virgil's Aeneid who guards the door of the Underworld into which Aeneas is to venture" (Watts, 1977, p.53). While, if viewed non-metaphorically, the two women's unconcerned look is just a result of their 'professional' occupation with what they are doing. The young woman shows Marlow into the waiting-room without stopping her knitting. And when Marlow comes out of the waiting-room, they are still knitting black wool 'feverishly.' To them, where Marlow and other young men will go and what would become of them are none of their business. Their interest is only in their domestic chores. Like the aunt, they stay only in their own world, though it may be built on the basis of lies.

Of all the women characters, Kurtz's Intended will be most faithful to lies and will surely spend the rest of her life in the world of illusion. It is more than one year since Kurtz's death, yet the Intended would like to "remember and mourn for ever" (Conrad, 1981, p. 126). Her abiding admiration for Kurtz's nobility, eloquence and genius makes Kurtz a kind of god figure to her. Though Kurtz died, he still thrones in her mind. When she tells Marlow that Kurtz has the capacity of drawing men towards him by what is best in them, when she interrupts Marlow's words "It was impossible not to..." and eagerly finishes it by "love him"(p. 127), she seems to be winning Marlow over to idolize Kurtz as she does. It is an honor for her to be loved by such a great man, and she is proud of having all Kurtz's "noble confidence." She is convinced that Kurtz never betrayed their love and Kurtz died for his noble cause. When she talks, "her forehead, smooth and white, remained illumined by the unextinguishable light of belief and love" (p. 127). Before such a woman who is "one of those creatures that are not the playthings of Time" (p. 126), Marlow cannot harden himself as to tell her the truth of what Kurtz did in the Congo and what he pronounced on his deathbed. Therefore, when the Intended insists that Marlow repeat to her Kurtz's last words so that she could have something to live with, Marlow lies by saying that Kurtz's last words are her name. With Marlow's lies, the Intended could live forever in her fanciful world in which she could possess Kurtz's devoted love and take pride in Kurtz's contribution to the great cause of Belgian government.

Like the Intended, Kurtz's lover in African tribe, that savage and superb queen-like woman, is also cut off from the reality. Marlow sees her twice, and in both cases he detects in her something tragic, though she walks in a stately imposing manner. The first time she appears near the steamer, "Her long shadow fell to the water's edge. Her face had a tragic and fierce aspect of wild sorrow and of dumb pain mingled with the fear of some struggling, half-shaped resolve" (p. 103). The second time is when the steamer brings Kurtz back to the Central Station. Even if Marlow pulls the string of whistle to frighten the tribesmen away, the superb woman does not flinch. She "stretched tragically her bare arms after us over the somber and glittering river" (p. 115). She knows Kurtz will never return. But her tragedy is that she never knows the inner struggle of Kurtz between civilization and savagery, nor she knows Kurtz's revulsion and repulsion at this savage life. She can deceive herself by believing that Kurtz has been 'kidnapped' away and will live with memory of Kurtz's love as the Intended does.

All these female characters in Heart of Darkness are isolated from the real world, living in their own small world of ignorance. This isolation may on the one hand be seen as "human capacity for imaginative illusions, for escaping from the concrete" (Hawthorn, 1979, p. 33), and on the other hand may serve as an extension of the deceptive nature of imperialism. As Jeremy Hawthorn (1979) argues, "imperialism demands that sections of the domestic power retain their illusions, and thus the human relationships of that domestic power are impregnated by the lies of imperialism through and through" (p. 33). So when Marlow lies to the Intended, he indirectly becomes an accomplice of imperialism in that he helps create the lies and illusions upon which imperialism thrives.

\section{Kurtz's Self-deception}

Due to Kurtz's deathbed pronouncement and the ideas he embodies, Heart of Darkness is more often read as the tale of Kurtz than that of Marlow. Within the larger context of the unknown narrator's record of Marlow's purging experience in Africa lies Marlow's search for Kurtz, the life and death of the latter enlightens the former who then spreads the latter's voice to every living soul.

After Marlow comes to Africa, he finds that the name of Kurtz is on the tip of every tongue. The Chief Accountant, the manager and the brickmaker all claim that Kurtz is the most capable agent and will go far in his career. Marlow's interest in this man is thus aroused by their constant reference. Yet, at this stage, Kurtz only remains as a remarkable ivory collector. It is until he sees Kurtz's painting at the brickmaker's room that Marlow for the first time asks earnestly to know more about this man. In Kurtz's painting of the blindfolded woman holding a lighted torch, Marlow is amazed at his penetrating insight into the true nature of western civilization, which suddenly collapses at his stroke. More than that, Marlow seems to envision the pains of Kurtz when his ambition of lighting up the darkness can never be fulfilled within the context of colonialism. From that moment on, Kurtz becomes a mystery for Marlow to unravel, a voice to follow and an ally to defend.

Kurtz has artist's expressiveness, politician's eloquence, poet's passion and journalist's perception. More importantly, he is nurtured in European culture which holds itself superior to any other culture. Because of these characters working together in him, he enthusiastically answers the call of imperialism with an ambition to turn the savage Africa into a new land of civilization. At the beginning of his African experience, he dutifully writes a report for the International Society for the Suppression of Savage Customs. It is a 17 pages of eloquent and beautiful writing, which explicitly exhibits Kurtz's mind as a European and expresses his altruism. What is most impressive with this writing is its ending phrase 'Exterminate all the brutes!', which is "scrawled evidently much later, in an unsteady hand" (Conrad, 1981, p. 
84). The difference of time for writing this end and the "unsteady hand" to write it, together with the painting, fully evidence the change of Kurtz's perception. When he writes 'Exterminate all the brutes,' he has not only savage Africans in mind, but also his countrymen, his European fellows, even himself. Otherwise he would not have repeatedly pleaded with Marlow to take good care of this 'pamphlet' as "it was sure to have in the future a good influence upon his career" (p. 85). Kurtz has been exposed to the greedy side of colonialism and imperialism. The means the agents use to subdue the natives reveal to him the savage nature inhering in every human being. Placed among the dark beings and amidst the primordial forest, he also keenly feels the primitive force in him and yields to it. By exerting what is most dark in him, he becomes the first class agent who can make "as much ivory as all the others put together" (p. 30). The heads hung on the stakes near his house are a most direct, hard but cruel fact of Kurtz's ferocity. His own act is enough for him to see into the human heart as an abysmal fountain of evils.

Though he succumbs himself to wilderness, the power of civilization does not completely give away. That holy mission never escapes him. When he finds it futile to rely on any institution to carry out that noble cause, he decides to take it up himself. Therefore, when he is already on the way back to the Central Station, he suddenly decides to go back. As Kurtz later confesses to Marlow, he has immense plans. "I was on the threshold of great things," but the manager's coming interrupts his plan. "I'll carry my ideas out yet--- will return. I'll show you what can be done. You with your little peddling notions---you are interfering with me" (p. 104). The great plans in his mind are not material aspirations though he has made too much of them by his force, but that noble cause which has called him there.

Even if neither the Russian admirer nor Kurtz himself releases much information about the ways he will reach his goal, the readers can still gather some information from the Russian that the natives adore Kurtz. "They would not stir till Mr. Kurtz gave the word. His ascendancy was extraordinary. The camps of these people surrounded the place, and the chiefs came every day to see him" (p. 98). Obviously, Kurtz has made himself a god to the natives. As he suggested in his writings that European whites "must necessarily appear to them [savages] in the nature of supernatural beings--we approach them with the might as if a deity" (p. 84). Kurtz might believe that by becoming a divine figure, he will be able to impose his will and his concept of civilization onto his believers. Thus his beautiful design will become a reality. As Jacques Berthoud (1979) has pointed out:

what finally damns Kurtz is not the horror of the shrunken heads which decorate his house, nor even the ferocity of his raiding excursions, but what these things indicate, the appalling fact that he has taken upon himself the role of God. This is tantamount to saying that he has entered into a state of final self-deception. (p. 54)

Yet, the problem is that when Kurtz conceives himself as a god who can 'swallow all the air, all the earth, all the men before him" (Conrad, 1981, p. 101), he is oblivious of the paradox of his plan, that is when he uses force to subjugate the natives and make them worship him, he is unconsciously engulfed by the power of darkness. At the time he becomes a god, he also turns to be a devil.

\section{MARlOW's HatRed OF LIES}

When the manager, the brickmaker and the pilgrims tell lies to clear off the obstacles in their way of success and fortune; when the women live in their world of illusions as an escape from the harsh reality; when Kurtz creates a lie about himself as a god figure to make it a necessary step of his grand design, Marlow endeavors to break the lies of the people and of imperialism, but sometimes he is also trapped in lies.

Many times in his narrative to the four listeners on the Nellie, Marlow claims that he prefers to facts and admires simplicity:

You know I hate, detest and can't bear a lie, not because I am straighter than the rest of us, but simply because it appalls me. There is a taint of death, a flavor of mortality in lies---which is exactly what I hate and detest in the world---what I want to forget. It makes me miserable and sick, like biting something rotten would do. Temperament, I suppose. (Conrad, 1981, p. 44)

Because of this temperament, he feels so uncomfortable when his noble-minded aunt talks about his holy mission and he has to make her know that the company he will work for is a business concern. Also, the plotting air at the Central Station disquiets him so much that he turns his back on that station and engages himself in his repair work. "In that way only it seemed to me I could keep my hold on the redeeming facts of life" (p. 37). Only in work can one have the chance to know himself, to know his own reality. Work does not cheat as words do. As Berthoud notices, "There is, to be sure, an essential difference between Marlow, who has passed the test of the sea, and so can distinguish between words and deeds, professions and performances, and the agents of the exploitative company he encounters in the Congo" (p. 44). This explains why Marlow values more the Russian Harlequin's book than Kurtz's report. Kurtz's report is beautiful and eloquent, but it is "too high-strung," full of burning noble words. While the Russian book titled An Inquiry into some Points of Steamship, despite its plain matter with illustrative diagrams and repulsive tales of figures, strikes Marlow as an extraordinary find. "I handled this amazing antiquity with the greatest possible tenderness, lest it should dissolve in my hands... Not a very enthralling book; but at the first glance you could see there a singleness of intention, an honest concern for the right way of going to work"(p. 63). Both the report and the book are works of written words, but what differs them is that the report is closer to an eloquent speech of a European colonizer, and the book is a simple true-to-life document of the real work.

No matter how detestable and mortal lies sound to him, sometimes Marlow intentionally involves himself in lies. At 
least he lies twice. In his confrontation with the brickmaker, Marlow learns that the brickmaker believes that both he and Kurtz have influential backgrounds back in Europe and if possible he hopes Marlow to say something nice of him to Kurtz. Marlow does not deny his unfounded supposition, instead he lets the brickmaker talk on and even assures him that rivets are also what Mr. Kurtz wants. This lie works. The brickmaker writes to the Outer Station for the supply of rivets. The second time happens when he meets the Intended. Marlow lies to her about Kurtz's last words. Unlike other liars who are unreflective of their words, Marlow is tortured with a sense of guilt. After his first lie, he turns immediately to his work so that he could hold onto the "redeeming facts of life." After the second lie, he feels that "the house would collapse before I could escape, that the heavens would fall upon my head" (p. 131). But nothing happens. In the light of the humanitarian concern underlying these two lies and his self-reproach, Marlow should be spared from criticism. And Marlow's case seems to point to one fact that no one can escape from lies.

\section{CONCLUSION}

In consideration of Marlow's persistent search for Kurtz and his voice, the journey into Africa is Marlow's journey of knowledge. Kurtz's deathbed pronouncement "The horror! The horror!'(Conrad, 1981, p. 118) initiates Marlow into reflecting upon the nature of colonialism and western civilization, the nature of humanity and human perception of their nature. In the meantime Marlow through his personal experiences and observations is also shocked into the knowledge of another horror: that is lies fill our life.

\section{ACKNOWLEDGEMENT}

The author is greatly indebted to the supervision of Professor Yaoxin Chang who has offered many valuable advices on the completion of this paper and given careful corrections to its language and structure.

\section{REFERENCES}

[1] Berthoud, Jacques (1979). Joseph Conrad The major phase. London: Cambridge University Press.

[2] Conrad, Joseph (1981). Heart of Darkness and The Secret Sharer. New York: Bantam Books.

[3] Hawthorn, Jeremy (1979). Joseph Conrad: Language and Fictional Self-Consciousness. London: Edward Arnold Ltd.

[4] Murfin, Ross C. Ed. (1996). Heart of Darkness Joseph Conrad. Case Studies in Contemporary Criticism. Boston: Bedford Books.

[5] Watts, Cedric (1977). Conrad's Heart of Darkness. Milano, Great Britain: Mursia International.

Deyan Guo is a Ph. D. candidate of English literature at College of Foreign Languages, Nankai University. Currently she also holds a teaching post as Associate Professor at Tianjin Foreign Studies University. Her academic interests cover contemporary British and American literature. 